\title{
PRODUCTION OF SHAPED SEMI-PRODUCTS FROM AHS STEELS BY INTERNAL PRESSURE
}

\author{
IZDELAVA POLPROIZVODOV IZ AHS-JEKEL, OBLIKOVANIH Z \\ NOTRANJIM TLAKOM
}

\author{
Ivan Vorel $^{1}$, Hana Jirková ${ }^{1}$, Bohuslav Mašek ${ }^{1}$, Petr Kurka ${ }^{2}$ \\ ${ }^{1}$ University of West Bohemia in Pilsen, Research Centre of Forming Technology, Univerzitni 22, 30614 Pilsen, Czech Republic \\ ${ }^{2}$ Fraunhofer Institute for Machine Tools and Forming Technology IWU, Reichenhainer Straße 88, 09126 Chemnitz, Germany \\ frost@vctt.zcu.cz \\ Prejem rokopisa - received: 2014-09-04; sprejem za objavo - accepted for publication: 2014-11-05
}

doi:10.17222/mit.2014.218

\begin{abstract}
The constant evolution of industry brings demands for components of ever-higher quality, complex shapes and excellent mechanical properties, with reduced operating costs and with improved reliability in service. Such demands can be met by processing high-strength, low-alloyed steels using novel heat-treatment methods. One of such methods is the quenching and partitioning (Q\&P) process, which can lead to high strengths of about $2000 \mathrm{MPa}$ at elongation levels of more than $10 \%$. The $\mathrm{Q} \& \mathrm{P}$ process can be combined with unconventional procedures for making complex-shaped parts to manufacture components with excellent mechanical properties and an intricate shape. This paper describes the sequence of internal high-pressure forming, hot stamping and the Q\&P process used for making a functional product with good mechanical properties and a complex shape. The purpose of the experimental programme was to employ a production chain for processing hollow, thin-walled stock. Using a step-by-step optimization, commercially usable products were obtained. The microstructure of the products consisted primarily of martensite and a small fraction of bainite. Such a microstructure guarantees a high ultimate strength. The strength level throughout the part was not less than $1950 \mathrm{MPa}$, combined with an excellent elongation of approximately $15 \%$.
\end{abstract}

Keywords: Q\&P process, hot stamping, internal high pressure forming

Stalen razvoj industrije zahteva komponente vedno boljših kvalitet, kompleksnih oblik, odličnih mehanskih lastnosti pri nižjih proizvodnih stroških in $\mathrm{z}$ večjo zanesljivostjo obratovanja. Take zahteve se lahko dosežejo $\mathrm{z}$ izdelavo visokotrdnostnih malolegiranih jekel z uporabo novih metod toplotne obdelave. Ena od takih metod je postopek kaljenja in delitve (Q\&P), ki omogoča velike trdnosti okrog $2000 \mathrm{MPa}$ pri več kot 10-odstotnem raztezku. Postopek Q\&P se lahko kombinira z nekonvencionalnimi metodami izdelave delov s kompleksno obliko in za izdelavo komponent z odličnimi mehanskimi lastnostmi in komplicirano obliko. Predstavljeni članek obravnava zaporedne operacije notranjega visokotlačnega preoblikovanja, vročega stiskanja in Q\&P-postopka za izdelavo funkcionalnih proizvodov z dobrimi mehanskimi lastnostmi in zapleteno obliko. Namen eksperimentalnega dela je bil postaviti proizvodno verigo za izdelavo votlih tankostenskih kosov. Z optimizacijo korak za korakom so bili izdelani komercialno uporabni proizvodi. Mikrostruktura proizvodov je bila sestavljena predvsem iz martenzita in majhnega deleža bainita. Taka mikrostruktura zagotavlja veliko natezno trdnost. Nivo trdnosti po vsem kosu ni bil manjši od $1950 \mathrm{MPa}$ v kombinaciji z odličnim raztezkom okrog $15 \%$.

Ključne besede: Q\&P-proces, vroče stiskanje, preoblikovanje z velikim notranjim tlakom

\section{INTRODUCTION}

Advanced high-strength steels (AHSS) find an everincreasing number of uses in a wide range of industrial sectors. Thanks to their excellent mechanical properties, they become the materials of choice for structural parts, which can thus be more lightweight than, but equally reliable and safe as, those made of conventional steels. Due to the continuously evolving needs of industry, new processing methods must always be sought to be combined in a comprehensive production chain.

\section{Q\&P PROCESSING}

The Q\&P process is an advanced method of heat treatment for high-strength steels. ${ }^{1}$ It relies on the processes that take place in the steel between the $M_{\mathrm{s}}$ and $M_{\mathrm{f}}$ temperatures and are related to carbon diffusion. Carbon migrates from the super-saturated martensite to the retained austenite, making the latter more stable. The $\mathrm{Q} \& \mathrm{P}$ process comprises heating to the austenitizing temperature and quenching to the quenching temperature (QT), which lies between the $M_{\mathrm{s}}$ and $M_{\mathrm{f}}$ temperatures. This produces a mixture of martensite and retained austenite. ${ }^{2,3}$ The workpiece is then heated to, and held at, the partitioning temperature (PT) ${ }^{4}$

With regard to the austenite stabilization, carbon must not precipitate in the form of carbides at the PT. To ensure this, aluminium, silicon or phosphorus should be used as alloying additions. In order to strengthen the solid solution, the steel can be alloyed with manganese and chromium. These elements shift the pearlitic and bainitic transformation curves in the transformation diagrams towards longer times, thus reducing the critical cooling rate. As silicon is present in the steel in order to retard carbide precipitation, the optimum level of chromium must be controlled, as chromium in the presence 
Table 1: Chemical composition of steel $42 \mathrm{SiCr}, w / \%$

Tabela 1: Kemijska sestava jekla 42SiCr, w/\%

\begin{tabular}{|c|c|c|c|c|c|c|c|c|c|}
\hline $\mathrm{C}$ & $\mathrm{Si}$ & $\mathrm{Mn}$ & $\mathrm{Cr}$ & Mo & $\mathrm{Nb}$ & $\mathrm{P}$ & $S$ & $M_{\mathrm{s}} /{ }^{\circ} \mathrm{C}$ & $M_{\mathrm{f}} /{ }^{\circ} \mathrm{C}$ \\
\hline 0.42 & 2.6 & 0.59 & 1.33 & 0.03 & 0.03 & 0.01 & 0.01 & 289 & 178 \\
\hline
\end{tabular}

of carbon acts as a carbide-former. The addition of manganese as an austenite-forming element effectively prevents any free ferrite from forming. Free ferrite can impair the mechanical properties of the steel..$^{5-7}$

\subsection{Internal High Pressure Forming}

This method can be used for manufacturing complex-shaped, hollow products. It is based on forming a hollow feedstock in a closed die using pressurized gas. The final temperature of the product can be controlled by changing the die-opening time. At the end of this die-opening time, the product is removed from the die and cooled in air or heat treated further.

\section{EXPERIMENTAL PROGRAMME}

The goal of the experimental programme was to form hollow feedstock using internal, high-pressure gas and then apply the Q\&P process. The experimental material was high-strength $42 \mathrm{SiCr}$ steel (Table 1). The initial microstructure of this steel consisted of ferrite and pearlite. The ultimate strength was $981 \mathrm{MPa}$, the elongation reached $30 \%$ and the hardness was $295 \mathrm{HV} 10$. Using the JMatPro software, the important $M_{\mathrm{s}}$ and $M_{\mathrm{f}}$ temperatures were found: $289^{\circ} \mathrm{C}$ and $178{ }^{\circ} \mathrm{C}$, respectively (Figure 1).

\subsection{Experimental Production of Shaped Products}

The hollow feedstock used for making the shaped products was $380 \mathrm{~mm}$ in length and $48 \mathrm{~mm}$ in diameter. Its wall thickness was $4 \mathrm{~mm}$ (Figure 2).

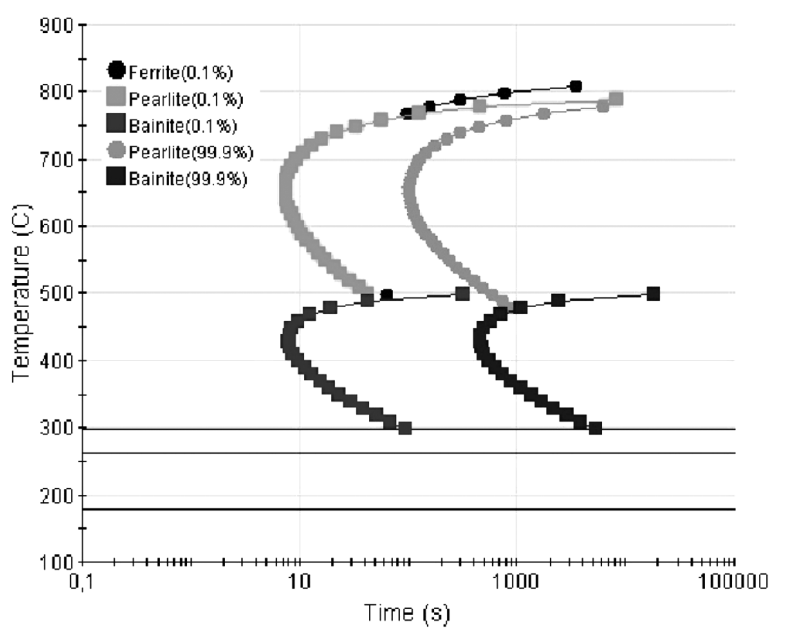

Figure 1: TTT diagram of 42SiCr steel calculated using JMatPro software

Slika 1: TTT-diagram jekla 42SiCr, izračunan s programsko opremo JMatPro

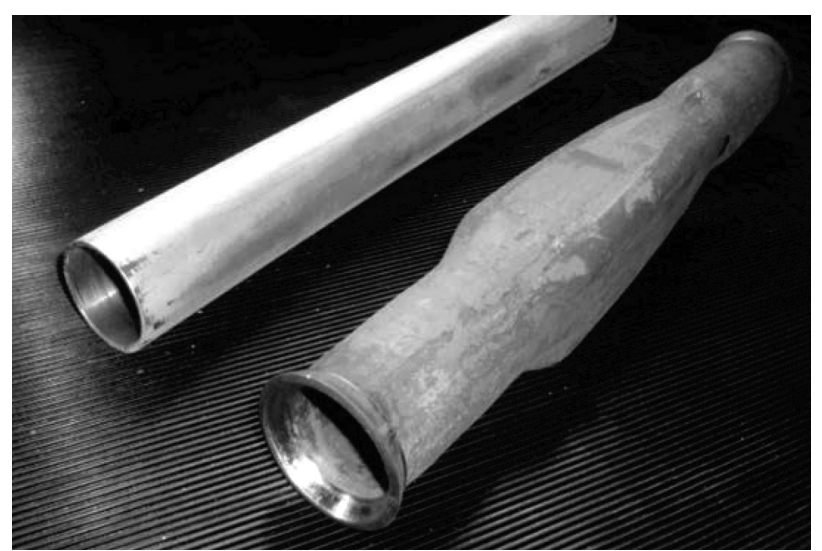

Figure 2: Experimental stock and the resulting shape after hot stamping

Slika 2: Preizkusni kos in dobljena oblika po vročem stiskanju

The sequence comprised heating to $915{ }^{\circ} \mathrm{C}$ and holding for $25 \mathrm{~min}$ to guarantee full austenitizing. Then the feedstock was transferred to a die at the ambient temperature. After the die was closed, the feedstock was formed by pressurized gas at an overpressure of 700 bar. The working gas was nitrogen. The contact between the workpiece and the die wall caused the workpiece to cool down rapidly to a pre-defined temperature. The die wall was at room temperature and was cooled by water. This was achieved by selecting the appropriate die-opening time between $5 \mathrm{~s}$ and $20 \mathrm{~s}$. After the die-opening time, the workpiece is removed. In order to explore the effect of $\mathrm{Q} \& \mathrm{P}$ processing, the final step of the proposed sequence, on the microstructure evolution and the related mechanical properties, the workpieces were further processed in three different ways (Figure 3). Some workpieces were cooled in air after hot stamping in the

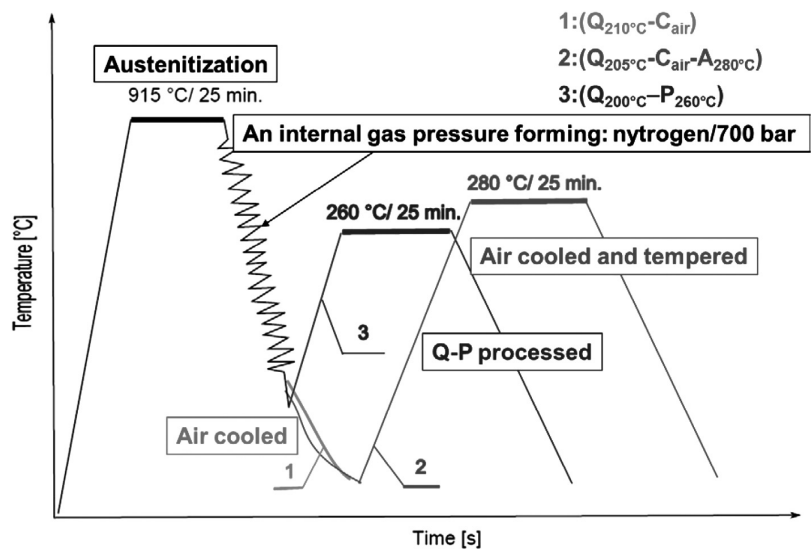

Figure 3: Experimental modes of heat treatment Slika 3: Eksperimentalni načini toplotne obdelave 
die. The product from this group was hot stamped in the die for $15 \mathrm{~s}$ and was then removed and cooled in air $\left(Q_{210}\right.$ $\left.{ }^{\circ} \mathrm{C}-C_{\text {air }}\right)$. The temperature at the moment of removal from the die was $210^{\circ} \mathrm{C}$. Another group comprised workpieces that were cooled in the die, then cooled in air to the ambient temperature and were then reheated in a furnace to $280{ }^{\circ} \mathrm{C}$, where they were held for $25 \mathrm{~min}$, and then removed and cooled in air. The product from the second group was cooled in the die for $15 \mathrm{~s}$ to a temperature of $205^{\circ} \mathrm{C}\left(Q_{150{ }^{\circ} \mathrm{C}}-C_{\text {air }}-A_{280}{ }^{\circ} \mathrm{C}\right)$. Yet another group included workpieces that were removed from the die and immediately placed in a furnace. The significant product from this third group was cooled in the die for $15 \mathrm{~s}$ as well. Then it was placed in a furnace and annealed at $260{ }^{\circ} \mathrm{C}$ for a time of $25 \mathrm{~min}\left(Q_{200{ }^{\circ} \mathrm{C}}-P_{200}{ }^{\circ} \mathrm{C}\right)$. The temperature after removal from the die reached $200{ }^{\circ} \mathrm{C}$ (Table 2). They were therefore treated using the $\mathrm{Q} \& \mathrm{P}$ process.

Table 2: Parameters of the experimental heat treatment Tabela 2: Parametri eksperimentalne toplotne obdelave

\begin{tabular}{|c|c|c|c|c|}
\hline & $\begin{array}{c}\text { Austeni- } \\
\text { tizing } \\
{ }^{\circ} \mathrm{C}\end{array}$ & \begin{tabular}{|c|} 
QT-tem- \\
perature \\
${ }^{\circ} \mathrm{C}$
\end{tabular} & $\begin{array}{l}\text { PT-tem- } \\
\text { perature } \\
{ }^{\circ} \mathrm{C}\end{array}$ & $\begin{array}{l}\text { Temper- } \\
\text { ing time } \\
\text { min }\end{array}$ \\
\hline$\left(Q_{210}{ }^{\circ} \mathrm{C}-C_{\text {air }}\right)$ & 915 & 210 & - & - \\
\hline$\left(Q_{205^{\circ} \mathrm{C}}-C_{\text {air }}-A_{280}{ }^{\circ} \mathrm{C}\right)$ & 915 & 205 & 280 & 25 \\
\hline$\left(Q_{200{ }^{\circ} \mathrm{C}}-P_{260}{ }^{\circ} \mathrm{C}\right)$ & 915 & 200 & 260 & 25 \\
\hline
\end{tabular}

\section{RESULTS AND DISCUSSION}

Representative products were selected from these groups of workpieces for metallographic examination and for mechanical property measurements. The specimens for the mechanical property measurement were taken from the products representing the different processing sequences. The specimen locations were chosen to allow an evaluation of the effects of the production sequence and of the position within the die upon the resulting product properties. Representative specimens were taken from the parts with which the workpiece was held in the die, from the area of the steepest change in cross-section, which is the point of the largest plastic strain, and from the transitions between the different diameters. A total of 14 test specimens were taken from each product (Figure 4)

Due to the shape of the workpieces, miniature tension test specimens with a gauge length of $5 \mathrm{~mm}$ and a crosssection of $2 \mathrm{~mm} \times 1.5 \mathrm{~mm}$ were used for measuring the mechanical properties (Figure 5).

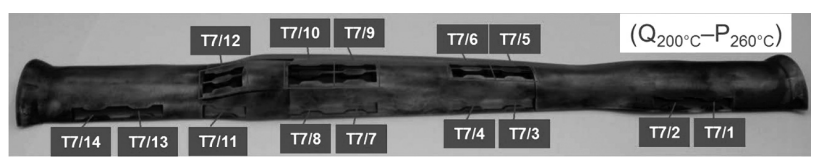

Figure 4: Selected locations of the $\mathrm{T} 7\left(Q_{200}{ }^{\circ} \mathrm{C}-P_{260}{ }^{\circ} \mathrm{C}\right)$ workpiece, upon the Q\&P process

Slika 4: Izbrana področja kosa $\mathrm{T} 7\left(Q_{200}{ }^{\circ} \mathrm{C}-P_{260}{ }^{\circ} \mathrm{C}\right)$ pri Q\&P-procesu

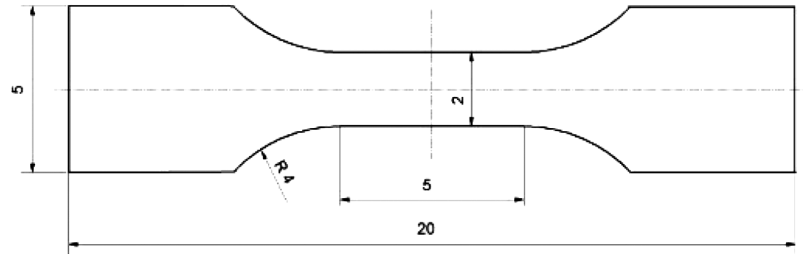

Figure 5: Shape of specimen for mechanical testing Slika 5: Oblika vzorca za mehanske preizkuse

\subsection{Mechanical Properties}

The product that was only cooled in air after removal from the die $\left(Q_{210}{ }^{\circ} \mathrm{C}-C_{\text {air }}\right)$ showed a very high ultimate strength (Table 3). None of the 14 specimens exhibited ultimate strengths of less than $2260 \mathrm{MPa}$. The elongation level was higher than $10 \%$ in all cases. The specimen with the lowest ultimate strength, $2263 \mathrm{MPa}$, and an elongation of $12 \%$, was $\mathrm{T} 3 / 5$, which had been taken from the transition to the largest diameter. It also showed the lowest hardness of all the specimens: $667 \mathrm{HV} 10$. It is likely that this part of the workpiece was not in full contact with the die wall. No similar effect of the specimen position was found in any other specimen from this product.

Table 3: Results of tensile testing (proof stress $R_{\mathrm{p} 0.2}$, ultimate tensile strength $R_{\mathrm{m}}$ and elongation $A_{5 \mathrm{~mm}}$ ) and hardness testing (HV10) of the semi-product $\left(Q_{210}{ }^{\circ} \mathrm{C}-C_{\text {air }}\right)$ upon air cooling

Tabela 3: Rezultati nateznih preizkusov (meja tečenja $R_{\mathrm{p} 0,2}$, natezna trdnost $R_{\mathrm{m}}$ in raztezek $A_{5} \mathrm{~mm}$ ) in merjenja trdote (HV10) polproizvodov $\left(Q_{210}{ }^{\circ} \mathrm{C}-C_{\text {zrak }}\right)$ po ohlajanju na zraku

\begin{tabular}{|c|c|c|c|c|}
\hline & $R_{\mathrm{p} 0.2} / \mathrm{MPa}$ & $R_{\mathrm{m}} / \mathrm{MPa}$ & $A_{5 \mathrm{~mm}} / \%$ & HV10 \\
\hline $\mathrm{T} 3 / 2$ & 1550 & 2324 & 14 & 709 \\
\hline $\mathrm{T} 3 / 3$ & 1534 & 2314 & 11 & 685 \\
\hline $\mathrm{T} 3 / 5$ & 1518 & 2263 & 12 & 667 \\
\hline $\mathrm{T} 3 / 8$ & 1641 & 2333 & 10 & 701 \\
\hline $\mathrm{T} 3 / 12$ & 1681 & 2345 & 10 & 738 \\
\hline $\mathrm{T} 3 / 14$ & 1652 & 2310 & 16 & 705 \\
\hline
\end{tabular}

All the specimens from the product $\left(Q_{205}{ }^{\circ} \mathrm{C}-C_{\text {air }}-\right.$ $\left.A_{280}{ }^{\circ} \mathrm{C}\right)$ exhibited ultimate strengths of more than 2110 $\mathrm{MPa}$ and $A_{5} \mathrm{~mm}$ elongation levels of more than $14 \%$ (Table 4). A low ultimate strength was found in the T6/5 specimen: $2133 \mathrm{MPa}$. The T6/5 specimen also showed $A_{5 \mathrm{~mm}}$ elongation of $18 \%$. This situation is similar to that in the product that was removed from the die and cooled

Table 4: Results of tensile testing of the semi-product $\left(Q_{150}{ }^{\circ} \mathrm{C}-C_{\text {air }}-\right.$ $A_{280}{ }^{\circ} \mathrm{C}$ )

Tabela 4: Rezultati nateznih preizkusov polproizvodov $\left(Q_{150}{ }^{\circ} \mathrm{C}-\right.$ $\left.C_{\text {zrak }}-A_{280}{ }^{\circ} \mathrm{C}\right)$

\begin{tabular}{|c|c|c|c|c|}
\hline & $R_{\mathrm{p} 0.2} / \mathrm{MPa}$ & $R_{\mathrm{m}} / \mathrm{MPa}$ & $A_{5 \mathrm{~mm}} / \%$ & HV10 \\
\hline $\mathrm{T} 6 / 2$ & 1822 & 2117 & 18 & 656 \\
\hline $\mathrm{T} 6 / 3$ & 1862 & 2160 & 17 & 653 \\
\hline $\mathrm{T} 6 / 5$ & 1838 & 2133 & 18 & 672 \\
\hline $\mathrm{T} 6 / 8$ & 1886 & 2189 & 18 & 637 \\
\hline $\mathrm{T} 6 / 12$ & 1771 & 2144 & 14 & 623 \\
\hline $\mathrm{T} 6 / 14$ & 1818 & 2196 & 19 & 671 \\
\hline
\end{tabular}



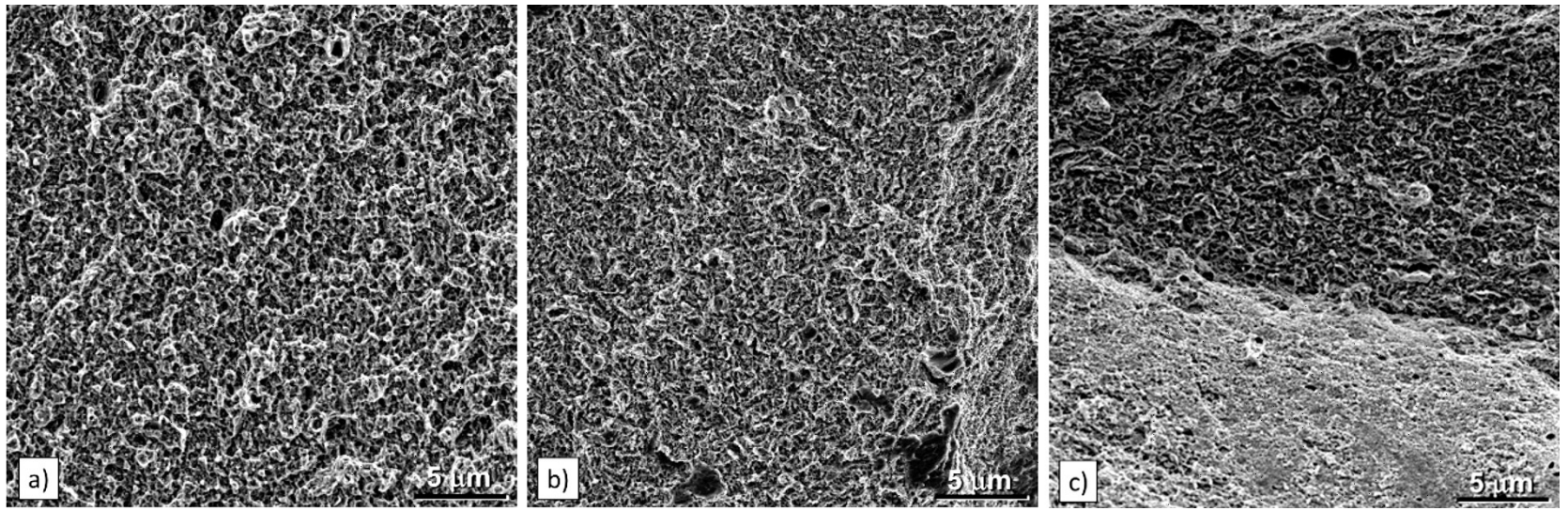

Figure 6: Fracture surfaces: a) $\mathrm{T} 3\left(Q_{200}{ }^{\circ} \mathrm{C}-C_{\text {air }}\right)$ product that was cooled in air $(\mathrm{T} 3 / 3)$, b) $\mathrm{T} 6\left(Q_{205}{ }^{\circ} \mathrm{C}-C_{\text {air }}-A_{280}{ }^{\circ} \mathrm{C}\right)$ that was cooled in air and then annealed in a furnace $(\mathrm{T} 6 / 3), \mathrm{c}) \mathrm{T} 7\left(Q_{200}{ }^{\circ} \mathrm{C}-P_{260}{ }^{\circ} \mathrm{C}\right)$ product after Q\&P process $(\mathrm{T} 7 / 3)$

Slika 6: Površine prelomov: a) $\mathrm{T} 3\left(Q_{200}{ }^{\circ} \mathrm{C}-C_{\text {zrak }}\right)$-proizvod, ohlajen na zraku $(\mathrm{T} 3 / 3)$, b) $\mathrm{T} 6\left(Q_{205}{ }^{\circ} \mathrm{C}-C_{\mathrm{zrak}}-A_{280}{ }^{\circ} \mathrm{C}\right)$, ohlajen na zraku in potem žarjen v peči $(\mathrm{T} 6 / 3), \mathrm{c}) \mathrm{T} 7\left(Q_{200}{ }^{\circ} \mathrm{C}-P_{260}{ }^{\circ} \mathrm{C}\right)$ proizvod po Q\&P-postopku $(\mathrm{T} 7 / 3)$

in air. By contrast, the hardness in the corresponding location of the latter product was the highest of all the locations tested: 672 HV10.

The ultimate strength of the product $\left(Q_{200}{ }^{\circ} \mathrm{C}-P_{260}{ }^{\circ} \mathrm{C}\right)$ was approximately $250 \mathrm{MPa}$ to $300 \mathrm{MPa}$ lower than that of the product that had been removed from the die and merely cooled in air (Table 5). In addition, it is approximately $150 \mathrm{MPa}$ to $200 \mathrm{MPa}$ lower than in the product that was removed from the die, cooled in air and then reheated to $280{ }^{\circ} \mathrm{C}$ and held for $25 \mathrm{~min}$. As in the previous cases, the lowest ultimate strength was found in the T7/5 location. It was $1914 \mathrm{MPa}$. The corresponding $A_{5 \mathrm{~mm}}$ elongation was $20 \%$ and the hardness reached 600 HV10. The specimens in the remaining locations exhibited strengths of approximately $2000 \mathrm{MPa}$. The Q\&P processing of the product improved its elongation. It was between $17 \%$ and $21 \%$.

Table 5: Results of tensile testing of the product $\left(Q_{200}{ }^{\circ} \mathrm{C}-P_{260}{ }^{\circ} \mathrm{C}\right)$ prepared using the Q\&P process

Tabela 5: Rezultati nateznih preizkusov proizvodov $\left(Q_{200}{ }^{\circ} \mathrm{C}-P_{260}\right.$ ${ }^{\circ} \mathrm{C}$ ), izdelanih po Q\&P-postopku

\begin{tabular}{|c|c|c|c|c|}
\hline & $R_{\mathrm{p} 0.2} / \mathrm{MPa}$ & $R_{\mathrm{m}} / \mathrm{MPa}$ & $A_{5 \mathrm{~mm}} / \%$ & $\mathrm{HV} 10$ \\
\hline $\mathrm{T} 7 / 2$ & 1576 & 1978 & 17 & 623 \\
\hline $\mathrm{T} 7 / 3$ & 1490 & 1956 & 21 & 615 \\
\hline $\mathrm{T} 7 / 5$ & 1379 & 1914 & 20 & 600 \\
\hline $\mathrm{T} 7 / 8$ & 1600 & 2006 & 18 & 596 \\
\hline $\mathrm{T} 7 / 12$ & 1584 & 1952 & 18 & 597 \\
\hline $\mathrm{T} 7 / 14$ & 1626 & 1978 & 17 & 608 \\
\hline
\end{tabular}

\subsection{Metallographic and Fractographic Characteriza- tion}

With reference to the results of the tension test, the fracture surfaces were examined. In all cases, ductile fractures with dimples were found (Figure 6). No signs of brittle fracture were detected, even in the product that was cooled in air after quenching in the die.

The microstructure was examined in locations corresponding to those of the samples taken for mechanical testing. In almost all the specimens taken from the product $\left(Q_{200{ }^{\circ} \mathrm{C}}-C_{\text {air }}\right)$ the microstructure consisted of martensite and a small proportion of bainite (Figure 7). Only those areas where the workpiece was not in full
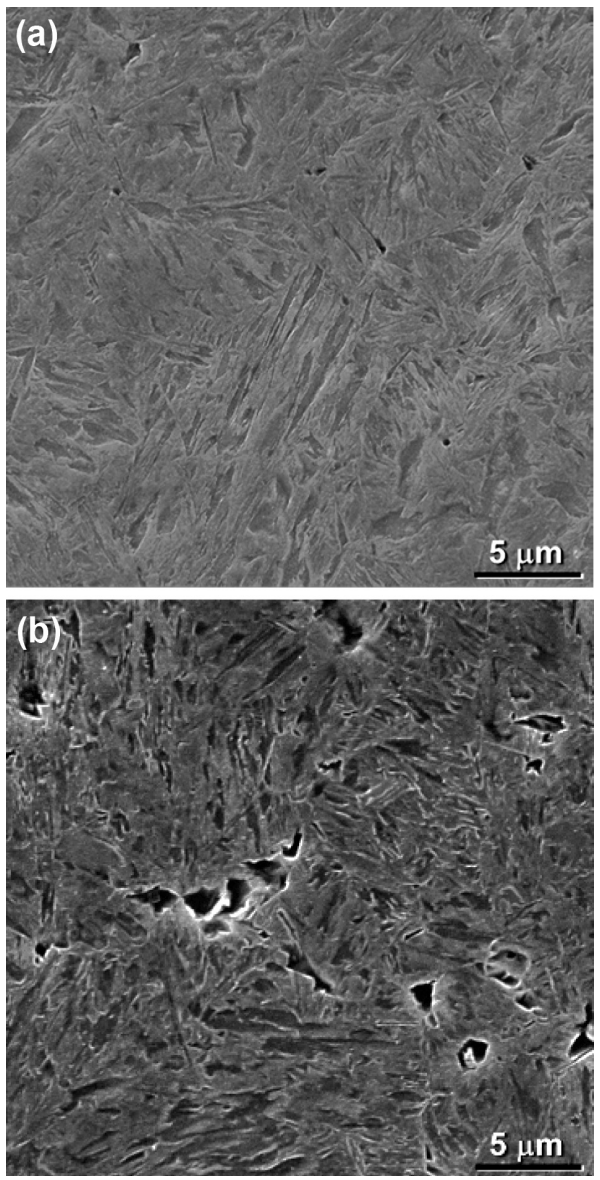

Figure 7: $\mathrm{T} 3\left(Q_{200}{ }^{\circ} \mathrm{C}-C_{\text {air }}\right)$ product upon air cooling: a) martensitebainite microstructure (point T3/2), b) martesite-bainite with a small fraction of ferrite (point T3/12)

Slika 7: T3 $\left(Q_{200}{ }^{\circ} \mathrm{C}-C_{\text {zrak }}\right)$-proizvod po ohlajanju na zraku: a) martenzitno-bainitna mikrostruktura (točka T3/2), b) martenzit-bainit z majhnim deležem ferita (točka T3/12) 

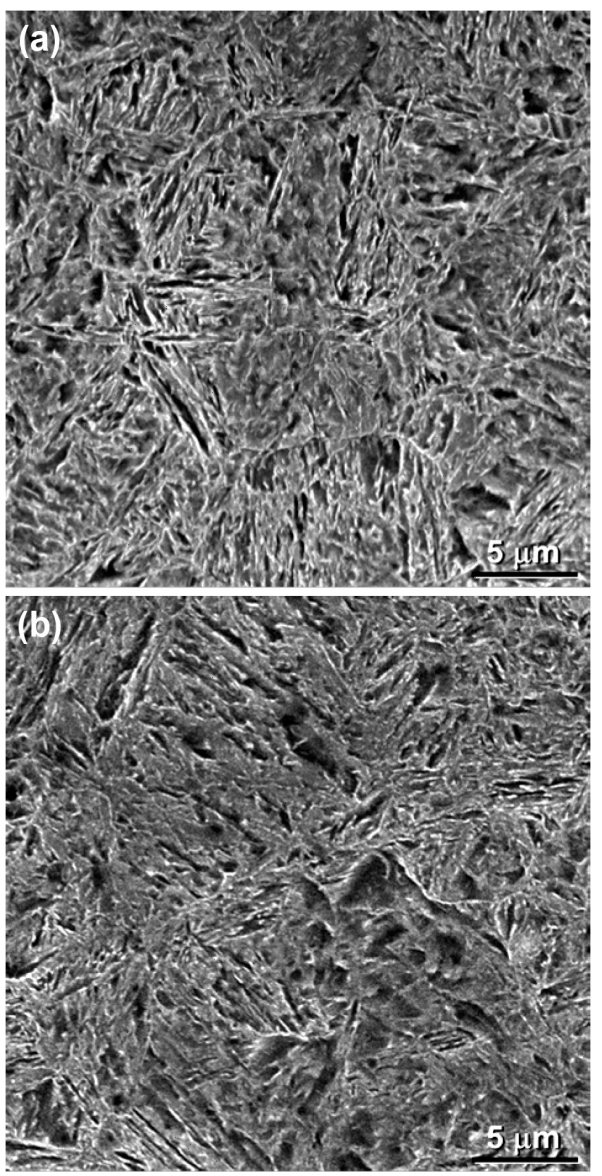

Figure 8: T6 $\left(Q_{205}{ }^{\circ} \mathrm{C}-C_{\mathrm{air}}-A_{280}{ }^{\circ} \mathrm{C}\right)$ product upon air cooling and annealing: a) tempered martensite-bainite microstructure (point T6/2) b) tempered martensite-bainite microstructure (point T6/12)

Slika 8: T6 $\left(Q_{205}{ }^{\circ} \mathrm{C}-C_{\text {zrak }}-A_{280}{ }^{\circ} \mathrm{C}\right)$-proizvod po ohlajanju na zraku in popuščanju: mikrostruktura: a) popuščeni martenzit-bainit (točka T6/2), b) mikrostruktura: popuščeni martenzit-bainit (točka T6/12)

contact with the die wall contain some free ferrite, which is probably due to the resulting insufficient cooling rate

An examination of the microstructure of the product $\left(Q_{205{ }^{\circ} \mathrm{C}}-C_{\text {air }}-A_{280}{ }^{\circ} \mathrm{C}\right)$ revealed tempered martensite and bainite (Figure 8). The locations where the workpiece was not in full contact with the die wall contained a small amount of free ferrite.

The Q\&P-processed product $\left(Q_{200}{ }^{\circ} \mathrm{C}-P_{260}{ }^{\circ} \mathrm{C}\right)$ contained a mixture of martensite and bainite (Figure 9). As in the products mentioned above, the locations of partial contact between the workpiece and the die wall contained a small amount of free ferrite.

\section{CONCLUSION}

Using internal high-pressure forming, products with complex shapes were obtained. A detailed inspection of their surfaces revealed no distinct discontinuities. In the product that was cooled in air after removal from the die, the $15 \mathrm{~s}$ in the die caused quenching to $210{ }^{\circ} \mathrm{C}$. Its microstructure was a mixture of martensite, bainite and a
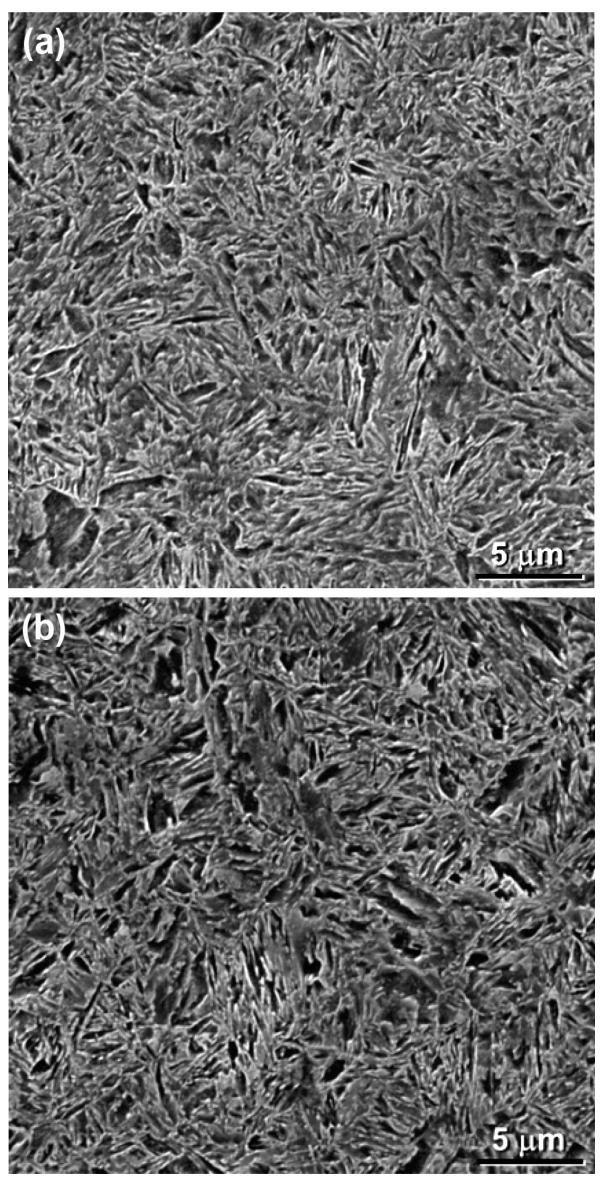

Figure 9: $\mathrm{T} 7\left(Q_{200}{ }^{\circ} \mathrm{C}-P_{260}{ }^{\circ} \mathrm{C}\right)$ product upon Q\&P process: a) martensite-bainite microstructure with a small fraction of ferrite (point $\mathrm{T} 7 / 2$ ), b) martensite-bainite with a small fraction of ferrite (point $\mathrm{T} 7 / 12$ )

Slika 9: $\mathrm{T} 7\left(Q_{200}{ }^{\circ} \mathrm{C}-P_{260}{ }^{\circ} \mathrm{C}\right)$ proizvod po Q\&P postopku: a) martenzitno-bainitna mikrostruktura $\mathrm{z}$ majhnim deležem ferita (točka T7/2), b) martenzit-bainit z majhnim deležem ferita (točka T7/12)

small proportion of free ferrite. No location of the product showed an ultimate strength of less than $2260 \mathrm{MPa}$. The elongation was more than $10 \%$.

The product that was cooled in air after removal from the die and then annealed in a furnace had a temperature of $205{ }^{\circ} \mathrm{C}$ after the $15 \mathrm{~s}$ die-opening time. The annealing of the product at $280{ }^{\circ} \mathrm{C}$ for 25 min produced a microstructure of tempered martensite, bainite and a small amount of free ferrite. No location of the product, where the mechanical properties were measured, showed an ultimate strength of less than $2110 \mathrm{MPa}$. Annealing after removal of the product from the die and subsequent cooling in air caused the elongation level to increase from 10 $\%$ to $14 \%$

Cooling in the die for $15 \mathrm{~s}$, which is used as part of the Q\&P process, led to the quenching of the product to $200{ }^{\circ} \mathrm{C}$. The subsequent reheating to the carbon-partitioning temperature of $260{ }^{\circ} \mathrm{C}$ and holding for $25 \mathrm{~min}$ resulted in a microstructure that consisted of tempered martensite, bainite and free ferrite. The ultimate strength of the product did not decrease below $1900 \mathrm{MPa}$ at any 
location. The Q\&P processing led to an increase in the elongation from $10 \%$ to $18 \%$.

The measurement of mechanical properties by means of tension testing did not identify any substantial effect of the location, and thus no substantial effect of the strain magnitude on the ultimate strength.

\section{Acknowledgment}

This paper includes results achieved in the project CZ.1.05/3.1.00/14.0297 Technological Verification of R\&D Results II, individual activity Hollow Shafts for Passenger Cars Produced by Heat Treatment with the Integration of Q-P Process and the project GAČR P107/12/P960 Influence of a Structure Modification on Mechanical Properties of AHS Steel. The paper also includes results from the project SGS-2013-028 Support of Students Research Activities in Materials Engineering Field.

\section{REFERENCES}

${ }^{1}$ L. Kucerova et al., Comparison of Microstructures and Properties Obtained After Different Heat Treatment Strategies of High Strength Low Alloyed Steel, Journal of Iron and Steel Research International, 18 (2011), 427-431

${ }^{2}$ J. Speer et al., Carbon Partitioning into Austenite after Martensite Transformation, Acta Materialia, 51 (2003), 2611-2622, doi:10.1016/S1359-6454(03)00059-4

${ }^{3}$ J. Speer et al., The Quenching and Partitioning Process: Background and Recent Progress, Materials Research, 8 (2005) 4, 417-423, doi:10.1590/S1516-14392005000400010

${ }^{4} \mathrm{~T}$. Tsuchiyma et al., Quenching and partitioning treatment of a low-carbon martensitic stainless steel, Materials Science and Engineering A, 532 (2012), 585-592, doi:10.1016/j.msea.2011. 10.125

${ }^{5}$ H. Jirkova, L. Kucerova, B. Masek, Effect of Quenching and Partitioning Temperatures in the Q-P Process on the Properties of AHSS with Various Amounts of Manganese and Silicon, Materials Science Forum, 706-709 (2012), 2734-2739, doi:10.4028/www.scientific. net/MSF.706-709.2734

${ }^{6}$ L. Kucerova et al., Optimization of Q-P Process Parameters with Regard to Final Microstructures and Properties, Annals of Daaam For 2009 \& Proceedings of the 20th International Daaam Symposium, 20 (2009), 1035-1036

${ }^{7}$ B. Masek et al., Improvement of Mechanical Properties of automotive Components Using Hot Stamping with Integrated Q-P Process, Journal of Iron and Steel Research International, 18 (2011) 1-2, 730-734 